- thirdly, in general it is necessary to approve the administrative (managerial) component of administrative-territorial units. After all, it is illogical for local state administration, district council and council of a united territorial community to exist at the same level of government (for example, district).

These issues are relevant and, in fact, their solution, in the process of decentralization, will overcome the challenges of political changes in Ukraine.

\title{
References:
}

1. Про схвалення Концепції реформування місцевого самоврядування та територіальної організації влади в Україні. Кабінет Міністрів України; Розпорядження, Концепція від 01.04.2014 № 333-p. URL: http://zakon5.rada.gov.ua/laws/show/333-2014-p. (дата звернення: 21.10.2020 p).

2. Президент Володимир Зеленський відкликає законопроєкт про внесення змін до Конституції щодо децентралізації влади. URL: https://www.ukrinform.ua/rubric-polytics/2857013-zelenskij-vidklikaeproekt-zmin-do-konstitucii-sodo-decentralizacii-op.html (дата звернення 22.10.2020 p).

3. Concept Paper on Decentralisation and Local Governance. Decentralisation and local governance: Module 1: Definitions and Concepts. 2007. 25 p.

DOI https://doi.org/10.30525/978-9934-588-91-4-35

\section{УКРАЇНСЬКЕ ГРОМАДЯНСЬКЕ СУСПІЛЬСТВО: ДО ОЦІНКИ НИНІШНІХ СПРОМОЖНОСТЕЙ ТА ПЕРСПЕКТИВ РОЗВИТКУ}

\author{
Корнієвський О. А. \\ доктор політичних наук, професор, \\ головний науковий співробітник \\ Національного інституту стратегічних досліджень \\ м. Київ, Украӥна
}

Перспективи сталого демократичного розвитку української державності обумовлюються не лише політичною еволюцією владних інститутів, а й насамперед - можливостями формування активного та високоорганізованого громадського сектору. Останнім часом дедалі помічаємо більшає ознак того, що він переживає черговий вирішальний 
етап своєї історії, підсумки якого стануть багато в чому визначальними як для власне українського громадянського суспільства, так і для утвердження демократії в Українській державі загалом.

\section{Подолати «точку біфуркації»}

Напередодні актуального «моменту істини» український громадський сектор виглядав досить солідно й переконливо, будучи репрезентованим найрізноманітнішими громадськими та волонтерськими ініціативами, організаціями, які користувалися стабільно високою суспільною довірою. Прикметно, що від початку нинішнього століття організована громадськість відігравала надзвичайно важливу роль у процесах зміни і демократичного транзиту політичної влади в Україні. Чималою мірою завдяки громадському активізмові було збережено державність за недієздатності низки офіційних інституцій у найкритичніші перші місяці 2014 року. Надалі частина представників організацій громадянського суспільства (ОГС) досить влилася в органи виконавчої влади та силові структури. У партнерстві з організованою громадськістю в країні стартувала низка складних і довготривалих реформ, успіх яких неможливий без системних змін - як у державній системі, так і в свідомості людей.

Однак, давно вже доведено, що становлення кожної політичної системи включає в себе не лише етапи стабільного існування, а й періоди екстремальних навантажень, які вимагають якісної трансформації напрацьованого. У теорії самоорганізації такі переломні моменти невизначеності отримали назву «точок біфуркації», адже вони завжди мають короткочасний характер і зазвичай розділяють більш тривалі стани функціонування Системи. В точці біфуркації найменший вплив іззовні може кардинально змінити напрямок розвитку, призвівши або до хаотизації, або до виходу на новий, еволюційно вищий рівень організованості. Власне, здатність долати точки біфуркації визначає загальну життєспроможність Системи - вона або пристосовується до нових умов, або розпорошується в ентропії.

Громадянське суспільство України сьогодні перебуває у своїй «точці біфуркації». Причинами дотеперішньої якісної стагнації громадського сектору на тлі цілком оптимістичної кількісної динаміки були не лише об'єктивна недостатність наявних форматів його взаємодії з тією чи іншою владною командою та суспільством загалом, а й задавнені внутрішні «хвороби росту», які були неподолані у часи пікової громадської активності 2013-2015 років.

Пандемія коронавірусу виявилася саме тим зовнішнім поштовхом, який лише унаочнив наявні вади й каталізував об'єктивні тенденції. Очевидно, що в багатьох аспектах «коронавірусний» світ тяжітиме до більшої локальності, деглобалізації, суверенізації окремих держав, до опертя передусім на внутрішні, національні ресурси та джерела розвитку. Відтак імовірною є деінтенсифікація глобального 
співробітництва у деяких сферах, надто - у не пов'язаних безпосередньо $з$ протидією пандемії. Приміром, від початку пандемічної кризи в світі вже відчутно деактуалізавалася навіть знакова для сучасного громадського активізму «кліматична агенда», пов'язана 3 проблемою глобального потепління. Усе це, з одного боку, звужуватиме перспективи міжнародної неурядової співпраці (зокрема окремих грантових програм), а 3 іншого - задаватиме нові рамки державно-громадської взаємодії всередині національних країн, потенційно сприяючи налагодженню тіснішого партнерства.

\section{Рух мас бути двостороннім}

Вимогою часу є переорієнтація українського громадського сектору на внутрішні ресурси розвитку та спроможності, зокрема фінансової. По-перше, шляхом організації постійної громадянської освіти та особистісного і професійного розвитку, обміну досвідом роботи, за якими обов'язково має йти практика. По-друге, все залежатиме від низових ініціатив громадян: важливо посилювати їх сталість та медійну присутність як всередині громади, так і поза нею; поширювати інформацію про те, як позитивний досвід забезпечення реалізації суспільних інтересів поширити повторити в інших громадах через соціальну проектну франшизу, що дозволить іншим мультиплікувати позитивні результати громадського соціально-значущого активізму. Для людей, які просувають низові ініціативи, важливим є бачити локальний результат і поширення своїх благих намірів.

Фандрейзингові зусилля ОГС очевидно мають більше спрямовуватися на національних замовників - від великих благодійників і меценатів до міноритарних платників членських внесків. Тільки так може бути сформовано природний, дійсно відповідний суспільним потребам «порядок денний» громадського активізму. Принципово важливо розвивати активності як у містах, так і в сільській місцевості. Адже децентралізаційна реформа виявила потужний потенціал сільських територій; відбувається активізація громад i, власне, відчуття себе частиною громади (не села, не району, а саме громади) є новим для пересічних людей на рівні сприйняття своєї ідентичності.

Безперечно, головним замовником для ОГС на «внутрішньому ринку» має виступати держава. Найперспективнішим напрямом співпраці визначимо аутсорсинг державних послуг, насамперед у сфері соціального забезпечення. Оскільки очевидно, що політико-владні інституції не можуть охопити весь спектр людських проблем, надто - на локальному рівні. Перебираючи на себе частину відповідних державних функцій, ОГС не лише виконуватимуть важливу суспільну місію, а підвищуватимуть власні дієспроможність та самозарадність. Держава також виграє, оскільки наразі саме недержавні провайдери є більш гнучкими і мобільними у справі впровадження інноваційних форм 
соціальних послуг, маючи для цього певні кадрові та матеріальнотехнічні ресурсами.

Своєю чергою, держава повинна забезпечити сприятливий організаційно-правовий режим діяльності неурядових суб'єктів, оптимізувавши середовище їхнього функціонування. Рух по лінії державногромадської взаємодії, безумовно, має бути двостороннім.

У цьому контексті серед необхідних змін, начастіше озвучуваних представниками українського громадянського суспільства, варто назвати такі: спрощення процесів реєстрації ОГС (зокрема повноцінне впровадження онлайн-реєстрації); усунення складностей надмірної банківської звітності ОГС; оновлення механізму податкової знижки для користувачів і запровадження механізму відсоткової філантропії на національному рівні; підвищення рівня освіченості та поінформованості громадськості про всі інструменти участі громадськості у формуванні та реалізації політичних, державно-управлінських рішень; об'єднання наявних інформаційних ресурсів щодо моніторингу нападів на громадських активістів та створення єдиного державного ресурсу систематизації таких нападів та їх моніторингу.

Існує і необхідність удосконалення державної підтримки та регламентації громадської, волонтерської та благодійної діяльності, спрямованої на задоволення повсякденних потреб різних соціальних груп. Першим кроком тут має стати формування єдиного загальнонаціонального реєстру надавачів соціальних послуг.

Окремий аспект - ініціативи в соціальному підприємництві: їх в Україні не бракує, але бракує інституційної підтримки для таких стартапів. А це справа державної значущості, оскільки соціально відповідальний бізнес є рушієм національної економіки. Маючи досвід реалізації локальних проектів, людина завжди зможе вийти на новий рівень. Самозарадність людини виявляється в їі бізнес-ініціативності. Тож постає необхідність впровадження державної програми сприяння таким підприємцям (наприклад, як в Естоніï).

\section{У майбутнс - $з$ оптимізмом}

2014 року активне громадянське суспільство допомогло державі встояти перед критичними внутрішніми і зовнішніми загрозами. Нині на порядку денному чергове не менш масштабне завдання - об'єднати державні та громадські можливості в умовах глобальної пандемічної кризи Лише солідарність, готовність до взаємодопомоги та людяність можуть подолати безпрецедентні виклики сьогодення.

Ситуація, коли держава і громадянське суспільство мусять зробити наступний крок назустріч одне одному, вчергове переосмисливши базові засади взаємин, назрівала роками. Коронакриза стала тригером, «спусковим гачком» давно назрілих зрушень i, водночас, - запорукою їх незворотності. Український громадський сектор має повернутися обличчям до реальних потреб людей. Нині маємо найкращу нагоду 
нарешті відповісти на питання: чи готове наше суспільство перейти на якісно новий рівень якості та сталості громадських ініціатив? Чи здатна вітчизняна організована громадськість «працювати» 3 викликами доби системно, а не лише на хвилі революційного піднесення?

За нинішньої складної соціально-економічної ситуації громадянське суспільство України дає надію і на успішне подолання нового періоду випробувань. Не підлягає сумніву наявність в українського громадського сектору великого й далеко не вичерпаного потенціалу розвитку. Здатність реалізувати потенціал громадського активізму є, без перебільшення, ключовою умовою демократичного майбутнього України. Тож, на наше переконання, завдання нинішньої політичної влади - забезпечити умови такої реалізації та створити чіткі організаційні алгоритми державно-громадської взаємодії, що має знайти своє відповідне відображення в новій Національній стратегії сприяння розвитку громадянського суспільства в Україні на 2021 - 2025 роки.

DOI https://doi.org/10.30525/978-9934-588-91-4-36

\title{
КУЛЬТУРНА ДИПЛОМАТІЯ ФРАНЦІЇ В СУЧАСНІЙ УКРАЇНІ
}

\author{
Луцишин Г. I. \\ доктор політичних наук, професор, \\ завідувач кафедри політології та міжнародних відносин \\ Національного університету «Львівська політехніка» \\ м. Львів, Украӥна
}

Сучасні держави за допомогою засобів і методів культурної дипломатії створюють свій позитивний образ на міжнародній арені, налагоджують взаємовигідне співробітництво і тісний діалог з іншими країнами. Культура допомагає дипломатії, сприяє нормалізації міжнародних політичних відносин, стимулює економіку. Крім того, культура виступає в якості важливого джерела зміцнення взаєморозуміння і солідарності, на яких будуються міцні відносини між націями і народами.

Для Французької Республіки, яка має багату культурну спадщину, просування своїх національних ідеалів і цінностей, особливо мови, традиційно є пріоритетним напрямком як внутрішньої, так і зовнішньої політики. Більш того, в них країна бачить дієвий інструмент «м'якого» впливу, значення якого в сучасних умовах переоцінити неможливо. Захист позицій французької мови та заохочення культурного розмаїття визначається в якості основних пріоритетів французької культурної дипломатії. 